\title{
Euroregional Multifunctionality and its Importance in the Activation of Border Areas
}

\author{
Marianna Greta \\ Ph.D., Professor at the Lodz University of Technology \\ Faculty of Management and Production Engineering \\ Department of European Integration and International Marketing, Lodz, Poland \\ e-mail: marianna.greta@p.lodz.pl
}

\section{Jacek Otto}

Ph.D., Full Professor at the Lodz University of Technology

Faculty of Management and Production Engineering

Department of European Integration and International Marketing, Lodz, Poland e-mail: jacek.otto@p.lodz.pl

\begin{abstract}
The study deals with the problems of Euroregions in the context of their multifunctionality. Multifunctionality is presented by analyzing the institutional structure and objectives pursued. The institutional structure presents the functions of individual Euroregional institutions and the importance of the Association of European Border Regions (AEBR) as the superior representation of Euroregions.

Referring to the objectives, they are presented in the light of the theoretical assumptions adopted for this type of structure, emphasizing that in their implementation there is a "hidden" multifunctionality of the Euroregion. In addition, the implementation of the objectives was verified in practice on the example of direct empirical research carried out in selected Polish Euroregions just after their creation and from the perspective of them operating for several years. Positive opinions in this respect, which prevail as integration awareness and the maturation of the Euroregion increases, support the establishment of such structures and verify their importance for the activation of border areas.
\end{abstract}

Keywords: European integration, region and regional policy, Euroregion

JEL: F15, R11 


\section{Introduction}

Euroregions have become a permanent element of post-war European integration, marking the ever-more pronounced influence on its functioning and achieved effects. Since the genesis of the first Euroregion (Euregio: Netherlands/Germany, 1958), sixty years have passed, and these structures still "surprise" with new forms of cooperation between the European Union (EU) member states. Establishing a Euroregion requires the participation of border regions from at least one Member State and means institutionalized cross-border cooperation. While the latter is practiced all over the world, Euroregions are a phenomenon of European integration and do not take place outside the Old Continent. However, they raise interest outside Europe as a "beneficial" structure on peripheral border areas. This impact on the border regions results from Euroregional multifunctionality and the purposes for which they were set up when the Germans sought the most favorable routes for the integration of war-torn Europe. This German idea for Euroregions has been successful, and the fact that they have functioned for several decades is an example of why this thesis should be defended. So far, none of the Euroregions has been dissolved and has not disappeared from the European Euroregional map; at most, they have suspended operations (e.g., the Polish Dobrawa Euroregion) as a result of financial difficulties. The "fashion" for Euroregions remains because the benefits that result from their impact on the border periphery are permanent. So, it seems interesting to devote some space to this current topic.

The multifunctionality of the Euroregion can be interpreted in different ways because the Euroregion, through binding the border areas, "takes control" over their development. Multifunctionality may result from actions that are taken in the Euroregion itself, as well as from the impact of the Euroregion on areas that do not belong to it. This is a very broad and difficult issue to cover with a narrow study.

In the light of the above remarks, the aim of the study is to present the Euroregion as an organized structure regarding the multifunctional impact on the borderland. The multifunctional impact on these areas is included for, among others, Euroregional purposes. Therefore, the following issues will be addressed in the study:

- the idea of Euroregions in institutional construction;

- Euroregional goals as a way to encourage multifunctionality;

- conclusions from empirical research on the meaning of the Euroregion for the borderland in the opinion of the "Euroregional population."

The purposefulness of presenting the above issues seems to be all the more important as Euroregional functionalism may turn out to be the key to smart specialization, and this, in turn, is the crown of modern integration in the EU and the implemented Europe 2020 Strategy development strategy. As a result, the Euroregion can contribute to following through the above-mentioned strategy and achieving the objectives of deeper integration in the EU. And just as the Euroregion was the first step to integration and a link in this integration, today it can be a way of deepening it, diversifying forms of cooperation, which is not without significance when the wave of criticism towards the integrative construction on the Old Continent is intensifying. 


\section{The idea of Euroregions - the institutional structure}

The idea of establishing Euroregions - and their special "mission" - lies in their organization in the form of institutional cross-border cooperation. In other words, the Euroregion is organized with the assistance of cross-border cooperation. Its typical design includes the Euroregional Council, secretariats and thematic working groups. These institutions are assigned specific tasks and a place in the Euroregion, thanks to which the Euroregion has a specific goal and tasks, and cooperation in the Euroregion, both internal and external, is ordered. The Euroregion Council is a representative and superior body defining the main directions of development and cooperation for the Euroregion. The Secretariat is an administrative body directed at servicing the activities of the Euroregion. On the other hand, thematic working groups determine the type of activities undertaken by the Euroregion. The greater the number, the wider the range of activities and work undertaken in the Euroregion, both internal and in cooperation with the broader external environment. More information about the institutions in the Euroregion and their functions is included in the table below (Table 1).

Thanks to the institutions described in Table 1, the Euroregion plan cooperate and participate in the development strategy of border areas, which (starting especially from 2007), have become a priority of EU regional policy in order to eliminate development disparities. And in this, i.e., in the professional institutionalization within the Euroregion, there is the Euroregion phenomenon, both for the development of peripheral regions as well as its importance for integration.

In addition to internal institutionalization, Euroregions "are subject" to certain rules of functioning within the framework of an external institution created by the Association of European Border Regions (AEBR). The association has a specific organizational structure within which the following institutions operate:

- The General Assembly, which with its the chairman decides on the membership of the Euroregions in the AEBR;

- The Executive Committee, which deals with the current activities of the AEBR, working out a strategy for cooperation with member Euroregions and other organizations regarding regions;

- The Secretary-General, who performs representative functions for Euroregions associated with the EU and other organizations (Greta 2011, pp. 35-41).

The AEBR performs a number of functions for its members, which can be reduced to the following:

- representation functions;

- advisory functions;

- so-called network functions.

More information on the above functions is provided in the table below (Table 2). 
Table 1. Institutions in the Euroregion and their functions

\begin{tabular}{|c|c|}
\hline $\begin{array}{l}\text { Name of the } \\
\text { institution } \\
\text { in the } \\
\text { Euroregion }\end{array}$ & The functions of institutions in the Euroregion \\
\hline Council & $\begin{array}{l}\text { It is the highest organ. It defines the main areas and directions of cooperation. } \\
\text { It sets strategic goals and the order in which they are achieved during joint } \\
\text { ventures. The Council acts as the coordinator of Euroregional cooperation. } \\
\text { It collects the necessary funds for its financing and supervises the directions it will } \\
\text { take. Typically, the Council is responsible for the selection of members in the other } \\
\text { organs of the Euroregion. In addition, it adopts the statute and regulations. Its } \\
\text { responsibilities include dealing with financial and budgetary matters. In the majority } \\
\text { of Euroregions, the Council performs the function of representing the union } \\
\text { externally. It is also the body that accepts or rejects proposals for resolutions. } \\
\text { The Council also decides on the admission of new members. }\end{array}$ \\
\hline Presidium & $\begin{array}{l}\text { It plays the role of the superior executive body. The tasks of the presidium include } \\
\text { the development and implementation of projects approved by the Council. } \\
\text { In this way, it gradually implements the tasks set by the Council. It represents } \\
\text { the Euroregion during the breaks of the Council in its deliberations. In addition, } \\
\text { it controls the work of the Secretariat, deals with the rights related to the use } \\
\text { of own resources, and approves material and financial plans. It also often designates } \\
\text { lesser execution structures. }\end{array}$ \\
\hline Secretariat & $\begin{array}{l}\text { It has an administrative role. It runs office affairs and organizes the work of other } \\
\text { bodies. The Secretariat is responsible for preparing the relevant documents and re- } \\
\text { ports for the Council and the Presidium. Its duties include organizing meetings, con- } \\
\text { ferences, and meetings of the Council and the Presidium. In addition, it supervises } \\
\text { the efficiency of work within the working groups. Like other parts of the Euroregion } \\
\text { structure, it performs a representative function of the organization outside. }\end{array}$ \\
\hline $\begin{array}{l}\text { Working } \\
\text { groups } \\
\text { (commis- } \\
\text { sions) }\end{array}$ & $\begin{array}{l}\text { They are the lowest executive and advisory cells. They deal with various problems } \\
\text { and issues on which cooperation within the Euroregion is concentrated. Each group } \\
\text { consists of experts and specialists in a given field. The task of these units is to } \\
\text { prepare and develop projects, assumptions of joint ventures. They carry out the } \\
\text { recommendations of the other authorities. }\end{array}$ \\
\hline
\end{tabular}

Source: Own elaboration based on statutes from Polish Euroregions: https://europa.eu/european-union/ index_en (accessed: 2.07.2018); http://www.coe.org.pl (accessed: 2.07.2018).

Table 2. AEBR - functions for Euroregions

\begin{tabular}{|l|l|}
\hline \multicolumn{1}{|c|}{ Type of function } & \multicolumn{1}{c|}{ Short characteristics } \\
\hline representative & $\begin{array}{l}\text { The AEBR is the only typical organization for the Euroregions that represents } \\
\text { them to the external environment. Therefore, it recognizes problems, } \\
\text { opportunities, and opportunities for cooperation. It initiates and coordinates } \\
\text { cooperation with various entities, including, inter alia, other Euroregions } \\
\text { or cross-border or border regions. } \\
\text { It helps in exchanging experiences or information to identify common } \\
\text { interests and coordinates their implementation and resolution. Performing } \\
\text { the above-mentioned tasks as part of the representational function, the AEBR } \\
\text { represents Euroregions, on, among others the EU and the Council of Europe } \\
\text { forum. }\end{array}$ \\
\hline
\end{tabular}




\begin{tabular}{|c|c|}
\hline Type of function & Short characteristics \\
\hline advisory & $\begin{array}{l}\text { This function is closely related to the representation function, as the AEBR } \\
\text { prepares the representation of Euroregions through counseling. } \\
\text { This advice includes: } \\
\text { - responding to Euroregional problems; } \\
\text { - participation in the development of joint Euroregional programs, projects, } \\
\text { and strategies; } \\
\text { - assistance in submitting applications for structural support from } \\
\text { Euroregional funds, } \\
\text { - indicating partners for joint implementation of projects. } \\
\text { - In addition, the AEBR acts as a service platform that facilitates the } \\
\text { exchange of know-how across Europe (Schmitt 2002, pp. } 271 \text { and later). } \\
\text { AEBR advises not only in economic but also socio-cultural aspects. }\end{array}$ \\
\hline Network & $\begin{array}{l}\text { It creates a network of links between cross-border regions and Euroregions } \\
\text { extending beyond the EU. The European AEBR network of links includes } \\
\text { more than one hundred and sixty of the border regions with different forms } \\
\text { of cooperation and organizational affiliation. As part of this function, the } \\
\text { AEBR initiates links, partnerships, and consultancy for the approximation } \\
\text { of border regions with similar interests and development goals, e.g., mountain, } \\
\text { coastal and rural areas. }\end{array}$ \\
\hline
\end{tabular}

Source: Greta 2013, pp. 79-80.

The functions described in Table 2, and the undertaken tasks within them, are not only a statutory record of the AEBR, but they translate into practical action in the various Euroregions so that Euroregions gain the possibility of having a wider presence on the pan-European forum, greater access to information, the exchange of experience and, above all, the creation of cooperation networks that strengthen integration within the integration group are possible.

"Bottom-up" institutionalization, namely internal Euroregional institutions, and "top-down" institutionalization, within the AEBR, affect the Euroregion itself and the areas it covers. Additionally, a "developed" Euroregion creates opportunities for further institutionalization related to the ordering and development of cooperation. The interaction can be illustrated in the diagram below (Figure 1).

\section{Association of European Border Regions (AEBR)}
Through institutionalization, it directly influences the Euroregion

Through development and continuous improvement, it directly influences the improvement and development of executed functions

Euroregion $=$ an organized cross-border region

It affects other "non-affiliated" border and internal areas in the home country as well as economic entities
The non-Euroregional experience is being exchanged to stimulate Euroregional multifunctionality

Fig. 1. Mutual Euroregional influences through institutionalization

Source: Own study based on long-term research and observations conducted in Polish Euroregions. 


\section{The idea of Euroregions - Multifunctionality}

\section{Multifunctionality - goals in Euroregions}

Both the "old" Western European Euroregions and the "young" Euroregions in Central and Eastern Europe were created to implement higher objectives, such as:

- changing the dividing nature of borders as historical scars to a peaceful, unifying character which is a bridge for cooperation;

- strengthening interpersonal bonds and good neighborly contacts on both sides of the border of neighboring countries;

- contributing to the increase of integration awareness built in the wider supranational integration grouping;

- limiting the problems of underdevelopment resulting from the peripheral location.

In retrospect, and from the point of view of sixty years of operation in Western Europe and nearly thirty years in Central and Eastern Europe, we can say that they have successfully implemented the above objectives and, in particular, the objective of integration. Euroregions have contributed to the consolidation of the EU in the sense of unity that did not threaten national states, and they were a bridge that brought new countries to the EU by enriching integration awareness devoid of unnecessary mistrust. However, the long-term functioning of Euroregions, in the sense that they do not threaten national states, has led to the expansion of objectives, tasks, and functions. There was also a kind of Euroregional specialization dictated by natural conditions that created regions, e.g., the tourist, agricultural, industrial or multi-sector. As Euroregional research shows, the current multifunctionality of Euroregions boils down to the following development priorities:

- improving interpersonal relations, combating prejudice and conflict;

- implementing the EU's subsidiarity principle by activating horizontal and vertical partnerships;

- improving cross-border infrastructure: border crossings, transport, and communication;

- exchanging experience and information on previous cooperation;

- preventing and combating natural disasters;

- shared spatial development plans;

- cultural exchange and care for cultural heritage;

- developing local entrepreneurship and improving the qualifications of the cross-border population;

- developing tourism as local entrepreneurship, including the development of agritourism and rural tourism;

- promotional activities for border areas;

- intensifying the use of EU assistance funds under the regional policy, Common Agricultural Policy and other sectoral policies, managing them, and implementing cross-border projects (Greta 2003, p. 93 and further). 
Years of empirical research conducted by the authors on the Polish borderlands show that emerging Euroregions try to incorporate all priorities because, in this way, they want to achieve the Euroregional benefits in economic and social development areas as quickly as possible. The older the Euroregion, the more specialized it is, which then limits the range of priorities to focus on the most important ones for the area which have the greatest expected benefits. The "Euroregional population" is also more and more decisive in choosing priorities; thus, they participate in local activities (Greta 2013, pp. 208-211). The Euroregional population focuses mainly on emphasizing the importance of social and economic benefits, while the Euroregional authorities, in addition to the above benefits, also put importance on pro-ecological activities and political benefits.

The "benevolent" operation of the Euroregion for peripheral areas, however, is associated with a number of constraints in the form of development barriers. Polish experience shows that the type and size of these barriers depend on the nature of the cooperating border, and it is supported by the Western experience. The correctness in this regard is that the Euroregional population draws attention mainly to the socio-cultural barriers, and that the Euroregional officials, in addition to the above, do not underestimate the economic and infrastructural barriers (Greta 2013, pp. 208-211).

\section{The importance of Euroregions for the borderland - conclusions from empirical research in selected Polish Euroregions}

This part of the work describes the importance of Polish Euroregions for the development of the borderland in the public opinion, analyzing this impact before and after Poland's accession to the EU. Of course, the importance depends on the degree of so-called Euroregional awareness, although as the Euroregion functions, this increases and levels out in relation to various Polish border areas. However, this awareness was always the greatest and the "oldest" on the Polish western border, where the "Euroregional population" knew the neighboring country the most, both in its positive and negative approaches. Below, in two identically structured tables (the same questions), information from Euroregions (two Euroregions from each borderland) was taken concerning knowledge about the Euroregion's impact. In the first of these tables (Table 3), this knowledge comes from the 1990s, or just after the creation of the Euroregion; in the second (Table 4), this knowledge comes from the period after 2004, i.e., from the perspective of several years of the Euroregion and Polish membership in the EU. 
Table 3. The importance of the Euroregion in the opinion of the "Euroregional population" before Poland's accession to the EU

\begin{tabular}{|c|c|c|c|}
\hline Specification & $\begin{array}{l}\text { Western borderland } \\
\text { (based on the } \\
\text { Pro Europa Viadrina } \\
\text { and Nysa Euroregions) }\end{array}$ & $\begin{array}{l}\text { Southern borderland } \\
\text { (based on the } \\
\text { Glacensis } \\
\text { and Carpathian } \\
\text { Euroregions) }\end{array}$ & $\begin{array}{l}\text { Eastern borderland } \\
\text { (based on the Bug } \\
\text { and Baltic Sea } \\
\text { Euroregions) }\end{array}$ \\
\hline $\begin{array}{l}\text { The goal of the } \\
\text { Euroregion }\end{array}$ & $\begin{array}{l}\text { Support for economic } \\
\text { development, cross- } \\
\text { border cooperation, } \\
\text { cooperation in the field } \\
\text { of education, youth } \\
\text { cooperation and the } \\
\text { removal of mutual } \\
\text { prejudices and the } \\
\text { integration dimension }\end{array}$ & $\begin{array}{l}\text { Supporting cultural } \\
\text { heritage, cooperation } \\
\text { in the field of tourism, } \\
\text { supporting economic } \\
\text { development }\end{array}$ & $\begin{array}{l}\text { Promotion of cultural } \\
\text { heritage, raising } \\
\text { professional } \\
\text { qualifications, } \\
\text { tourism development, } \\
\text { improvement of living } \\
\text { conditions of the local } \\
\text { community }\end{array}$ \\
\hline $\begin{array}{l}\text { Does the Euroregional } \\
\text { activity create } \\
\text { real opportunities } \\
\text { to deepen knowledge } \\
\text { about the community } \\
\text { of the other country } \\
\text { (real opportunities } \\
\text { for social and cultural } \\
\text { meetings and } \\
\text { exchanges) }\end{array}$ & $\begin{array}{l}\text { Definitely yes. There } \\
\text { are various forms } \\
\text { of cultural, sports } \\
\text { and scientific events, } \\
\text { Euroregional fairs }\end{array}$ & $\begin{array}{l}\text { Definitely yes: in the } \\
\text { Glacensis Euroregion, } \\
\text { the Tatras and } \\
\text { Carpathians; in other } \\
\text { Euroregions of this } \\
\text { borderland, this } \\
\text { knowledge is not } \\
\text { so obvious. There are } \\
\text { mostly cultural events }\end{array}$ & $\begin{array}{l}\text { In the Bug Euroregion, } \\
\text { individual affirmative } \\
\text { answers appeared, } \\
\text { but not in the other } \\
\text { Euroregions }\end{array}$ \\
\hline $\begin{array}{l}\text { Are the activities } \\
\text { in this area known? }\end{array}$ & Yes & $\begin{array}{l}\text { Where there is this } \\
\text { consciousness, it is } \\
\text { also yes }\end{array}$ & $\begin{array}{l}\text { It is difficult to give } \\
\text { an unambiguous } \\
\text { answer }\end{array}$ \\
\hline $\begin{array}{l}\text { How the existence } \\
\text { and activity of the } \\
\text { Euroregion affect } \\
\text { social relations } \\
\text { between the } \\
\text { neighboring } \\
\text { population: } \\
\text { - positively, } \\
\text { - negatively, } \\
\text { - there is no such } \\
\text { effect }\end{array}$ & Positively & Positively & $\begin{array}{l}\text { It is difficult to notice } \\
\text { such an impact, let } \\
\text { alone evaluate it }\end{array}$ \\
\hline $\begin{array}{l}\text { Has the development } \\
\text { of cross-border } \\
\text { cooperation } \\
\text { contributed to the } \\
\text { improvement of the } \\
\text { conditions and } \\
\text { living standards } \\
\text { of the Euroregion's } \\
\text { population }\end{array}$ & Yes & It is difficult to assess & Yes \\
\hline
\end{tabular}




\begin{tabular}{|c|c|c|c|}
\hline Specification & $\begin{array}{l}\text { Western borderland } \\
\text { (based on the } \\
\text { Pro Europa Viadrina } \\
\text { and Nysa Euroregions) }\end{array}$ & $\begin{array}{l}\text { Southern borderland } \\
\text { (based on the } \\
\text { Glacensis } \\
\text { and Carpathian } \\
\text { Euroregions) }\end{array}$ & $\begin{array}{l}\text { Eastern borderland } \\
\text { (based on the Bug } \\
\text { and Baltic Sea } \\
\text { Euroregions) }\end{array}$ \\
\hline $\begin{array}{l}\text { Does affiliation to the } \\
\text { Euroregion create } \\
\text { additional facilities } \\
\text { and opportunities for } \\
\text { economic exchange } \\
\text { with neighboring areas } \\
\text { and, in general, with } \\
\text { this country }\end{array}$ & Yes & Yes & Yes \\
\hline $\begin{array}{l}\text { Are there any } \\
\text { attempts or forms } \\
\text { of assistance from the } \\
\text { Euroregion authorities } \\
\text { in conducting } \\
\text { cross-border } \\
\text { cooperation }\end{array}$ & Yes & Yes & Yes \\
\hline $\begin{array}{l}\text { The role of the } \\
\text { Euroregion } \\
\text { in preparation for EU } \\
\text { accession }\end{array}$ & $\begin{array}{l}\text { High, thanks to EU } \\
\text { funds, ventures of an } \\
\text { integrative nature are } \\
\text { implemented }\end{array}$ & $\begin{array}{l}\text { The Euroregion } \\
\text { certainly brings the EU } \\
\text { closer by increasing } \\
\text { integration awareness } \\
\text { (Glacensis, Carpathian), } \\
\text { in other borderland } \\
\text { Euroregions this } \\
\text { assessment was more } \\
\text { restrained and hesitant }\end{array}$ & $\begin{array}{l}\text { From own Euroregional } \\
\text { experience, hard } \\
\text { to say, but in the Bug } \\
\text { Euroregion there was } \\
\text { such awareness, and } \\
\text { this is the Euroregion } \\
\text { bordering the } \\
\text { Carpathian Euroregion; } \\
\text { in the Baltic } \\
\text { Euroregion - not }\end{array}$ \\
\hline
\end{tabular}

Source: own study based on empirical research conducted directly in the above-mentioned Euroregions.

With the awareness of both Euroregionalization and integration, the "Western Euroregional population" considered that the activities of the Euroregion create a real opportunity to deepen knowledge of the neighboring country, even through a variety of cultural, sporting and scientific events. The same opinion prevailed among respondents of the Carpathian and Glacensis Euroregions, but it was not shared so clearly by the people of the Bug and the Baltic Euroregions; in other eastern areas there was a lack of experience. In the western and southern borderlands, there was a consensus that the existence of the Euroregion had a positive effect on social relations between the neighboring population, and it was difficult to assess such an impact on the eastern borderland. On the other hand, the question of whether the Euroregion contributes to an increase in the standard of living of the population (in the west, the answer was yes) was difficult to assess in the south, or rather not in the east. There was a consensus on all Polish borderlands that the Euroregion creates additional opportunities for economic exchange with neighbors and for the support and assistance of the Euroregional authorities in obtaining cross-border assistance. "Euroregional population of the western borderland" looked for a large integration role of the Euroregion 
based on the experience of using aid funds. Although the remaining "Euroregional population" (the southern, eastern and northern borderlands) did not have a positive experience in Euroregional use of funds, they did see the integration and European dimension of this form of cooperation. Irrespective of the assessment of the Euroregion for the border area, its presence in the structure of the area's functioning was noticed everywhere.

Systematic Euroregional studies in the subsequent years of Euroregions, their functioning and development, as well as "maturation," prove some changes in the meaning of the Euroregion among the "Euroregional population," especially in the eastern and northern Polish borderlands, and in the southern part. Poland has already become an EU Member State, and the Euroregions ceased to function as an EU accession tool providing information on this grouping. With the same questions (except the last one), the Euroregional people were asked to assess their knowledge and the evolution of the Euroregional approach. Information in this regard is collected and presented synthetically in Table 4.

Table 4. The importance of Euroregionalisation in the opinion of the "Euroregional population" after Poland's accession to the EU

\begin{tabular}{|c|c|c|c|}
\hline Specification & $\begin{array}{c}\text { Western borderland } \\
\text { (based on the } \\
\text { Pro Europa Viadrina } \\
\text { and Nysa Euroregions) }\end{array}$ & $\begin{array}{l}\text { Southern borderland } \\
\text { (based on the } \\
\text { Glacensis and } \\
\text { Carpathian } \\
\text { Euroregions) }\end{array}$ & $\begin{array}{l}\text { Eastern borderland } \\
\text { (based on the Bug } \\
\text { and Baltic Sea } \\
\text { Euroregions) }\end{array}$ \\
\hline $\begin{array}{l}\text { The goal of the Eurore- } \\
\text { gion }\end{array}$ & $\begin{array}{l}\text { Supporting economic } \\
\text { development, } \\
\text { cross-border } \\
\text { cooperation, } \\
\text { cooperation in the field } \\
\text { of education, youth } \\
\text { cooperation and the } \\
\text { removal of mutual } \\
\text { prejudices and the } \\
\text { European dimension, } \\
\text { as well as sustainable } \\
\text { development } \\
\text { respecting the } \\
\text { environment }\end{array}$ & $\begin{array}{l}\text { Supporting cultural } \\
\text { heritage, cooperation } \\
\text { in the field of tourism, } \\
\text { supporting economic } \\
\text { development, bringing } \\
\text { together local commu- } \\
\text { nities and developing } \\
\text { interpersonal relations }\end{array}$ & $\begin{array}{l}\text { Promotion of cultural } \\
\text { heritage, raising pro- } \\
\text { fessional qualifications, } \\
\text { tourism development, } \\
\text { improvement of liv- } \\
\text { ing conditions of local } \\
\text { communities, border } \\
\text { security state }\end{array}$ \\
\hline $\begin{array}{l}\text { Does the activity } \\
\text { of the Euroregion cre- } \\
\text { ate real opportunities } \\
\text { to deepen knowledge } \\
\text { about the communi- } \\
\text { ties of the other coun- } \\
\text { try (real opportunities } \\
\text { for meetings and so- } \\
\text { cio-cultural exchang- } \\
\text { es)? }\end{array}$ & $\begin{array}{l}\text { Definitely yes. There } \\
\text { are various forms } \\
\text { of cultural, sporting, } \\
\text { scientific events, } \\
\text { Euroregional fairs, } \\
\text { conferences, scientific } \\
\text { symposia, learning the } \\
\text { language of neighbors } \\
\text { and borderland history }\end{array}$ & $\begin{array}{l}\text { In the "old" study, this } \\
\text { opinion was quite ob- } \\
\text { vious in some Eurore- } \\
\text { gions. Today there are } \\
\text { not ordinary sporting } \\
\text { or tourism but cultural } \\
\text { and scientific events. }\end{array}$ & $\begin{array}{l}\text { The "old" opinions } \\
\text { were negative, and to- } \\
\text { day they have turned } \\
\text { into positive ones, } \\
\text { even in the youngest } \\
\text { Euroregions one feels } \\
\text { that whiff of the close- } \\
\text { ness of local commu- } \\
\text { nities, although some- } \\
\text { times hindered by the } \\
\text { state policy }\end{array}$ \\
\hline
\end{tabular}




\begin{tabular}{|c|c|c|c|}
\hline Specification & $\begin{array}{c}\text { Western borderland } \\
\text { (based on the } \\
\text { Pro Europa Viadrina } \\
\text { and Nysa Euroregions) }\end{array}$ & $\begin{array}{l}\text { Southern borderland } \\
\text { (based on the } \\
\text { Glacensis and } \\
\text { Carpathian } \\
\text { Euroregions) }\end{array}$ & $\begin{array}{l}\text { Eastern borderland } \\
\text { (based on the Bug } \\
\text { and Baltic Sea } \\
\text { Euroregions) }\end{array}$ \\
\hline $\begin{array}{l}\text { Are there any known } \\
\text { activities in this area? } \\
\text { (regarding point } 2 \text { ) }\end{array}$ & Yes & Yes & Yes \\
\hline $\begin{array}{l}\text { How the existence } \\
\text { and activity of the Eu- } \\
\text { roregion affect social } \\
\text { relations between the } \\
\text { neighboring popula- } \\
\text { tion: } \\
\text { - positively, } \\
\text { - negatively, } \\
\text { - there is no such ef- } \\
\text { fect }\end{array}$ & Positively & Positively & Positively \\
\hline $\begin{array}{l}\text { Has the development } \\
\text { of cross-border coop- } \\
\text { eration contributed } \\
\text { to the improvement } \\
\text { of the conditions and } \\
\text { living standards of the } \\
\text { Euroregion population? }\end{array}$ & Yes, very important & $\begin{array}{l}\text { Yes - mainly through } \\
\text { the development } \\
\text { of tourist services }\end{array}$ & $\begin{array}{l}\text { Yes - mainly through } \\
\text { job creation thanks } \\
\text { to a venture from the } \\
\text { structural funds }\end{array}$ \\
\hline $\begin{array}{l}\text { Does affiliation to the } \\
\text { Euroregion create } \\
\text { additional facilities } \\
\text { and opportunities for } \\
\text { economic exchange } \\
\text { with neighboring areas } \\
\text { and, in general, with } \\
\text { this country? }\end{array}$ & $\begin{array}{l}\text { Yes and to a significant } \\
\text { extent }\end{array}$ & Yes & $\begin{array}{l}\text { Yes, although Belarus, } \\
\text { for example, is a dif- } \\
\text { ficult partner, there } \\
\text { are high hopes for the } \\
\text { Eastern Partnership }\end{array}$ \\
\hline $\begin{array}{l}\text { Are there any attempts } \\
\text { or forms of assistance } \\
\text { from the Euroregion } \\
\text { authorities in conduct- } \\
\text { ing cross-border coop- } \\
\text { eration? }\end{array}$ & Yes & Yes & Yes \\
\hline $\begin{array}{l}\text { The role of Eurore- } \\
\text { gions in integration }\end{array}$ & $\begin{array}{l}\text { Big. Integration } \\
\text { for people against } \\
\text { economics takes place } \\
\text { here }\end{array}$ & $\begin{array}{l}\text { This role was mainly } \\
\text { associated with the } \\
\text { possibility of tourism } \\
\text { development }\end{array}$ & $\begin{array}{l}\text { This role was associ- } \\
\text { ated with increased } \\
\text { security and the availa- } \\
\text { bility of aid funds }\end{array}$ \\
\hline
\end{tabular}

Source: own study based on empirical research conducted directly in the above-mentioned Euroregions.

According to the information contained therein, some conclusions can be formulated: - the purpose of the Euroregion is more deliberately defined and understood, especially in the context of bringing together local communities, and attention is paid to border and environmental security, 
- even for the people of the eastern and northern borderland, today the Euroregion provides knowledge about the neighboring country and increases the sense of closeness,

- the positive assessment of the Euroregion's influence was maintained and even strengthened in the area of interpersonal relations of the local communities in the western and southern borderland; on the east and in the north, its character changed from there being a hardly noticeable influence - and therefore difficult to assess - to a positive one as well,

- the positive impact of the Euroregion on the quality of life was assessed positively on all border areas, although prior to 2004, research showed that this impact was felt positively only on the Polish western border,

- an interesting answer was given to the question posed: Does the Euroregion create opportunities for an intensification of exchanges with a neighbor? Admittedly, the "Euroregional population" emphasized such influence on all borderlands, but currently, it has new opportunities and opportunities for this impact on the eastern and northern borderland, which is connected with the Eastern Partnership,

- the wording of the last issue in the interview was changed. Earlier, the "Euroregional population" was asked about the role of the Euroregion in preparation for membership of the EU, while recently, they were asked about the role of the Euroregion in integration. In all borderlands, this role was assessed highly, but everywhere it was motivated by individual considerations, i.e., the southern border was associated with the possibility of developing modern tourism, and on the eastern and northern borders - with security and accessibility to "additional" aid funds resulting from the implementation of projects in Operational Programmes.

Thus, on all Polish borderlands, the "Euroregional population" feels their existence and functioning, and this applies both to supporters and opponents of Euroregions. However, there are far more supporters because social opinion evaluates through the prism of the benefits that it achieves and sees itself. So, the positive evaluation of the Euroregion also happens in those who have a generally skeptical attitude towards integration and the EU.

\section{Conclusion}

Regardless of the individual approach of various bodies and entities to the existence of Euroregions, the positive assessment of them prevails. However, it was not so positive in the Polish reality (and the study deals with Polish Euroregionalization), especially at the time of their formation in the 1990s. Then, various prejudices were voiced that Euroregions are a dangerous "solution," threatening national sovereignty and identity. The situation changed radically over the years when it turned out that 
Euroregions are not a threat, but they help economic development and have a broad "beneficial" impact on regions which are "lagging behind"; they also strengthen and enrich people-to-people relationships.

The phenomenon of the Euroregion lies in its multifunctionality, which it can implement in practice. This multifunctionality is diverse. The study refers to the organizational structure and objectives pursued. Multifunctionality is possible due to institutionalization, as the established institutions have strictly defined tasks to perform, and they also make the Euroregion a compact and durable construction, which is more than just a one-off, temporary act, as in the case of an agreement on cross-border cooperation between border regions. This institutionalization has both an internal dimension, i.e., a Euroregion together with institutions, as well as an external one, i.e., external representatives, e.g., AEBR (described in the study). External representatives disseminate knowledge about the Euroregion, as well as help in fulfilling the multifunctionality.

The multifunctionality of the Euroregion is most fully reflected in the objectives pursued related to the human, economic and integration dimension, and organized sporting or cultural-educational events are the strongest bond and the first step to take other joint cross-border activities. The awareness of multifunctionality goes hand in hand with integration awareness, but today it is already strong everywhere on the Polish borderlands. Even the mistrust of the eastern borderlands of Poland is changing, and the "eastern Euroregional population" is beginning to positively assess the impact of the Euroregion, especially on improving the quality of life and expanding the exchange opportunities with its neighbors. What is quite important in this context is that the Euroregional population in Poland recognizes the involvement of local and self-government authorities for the functioning of the Euroregion and the development of cooperation to promote multifunctionality, and activating impact on the borderlands.

\section{References}

Dołzbłasz, S. (2010), Współpraca transgraniczna $w$ Polsce po akcesji do UE, Wydawnictwo Wolters Kluwer Polska SA, Warszawa.

Dumała, H. (2000), Czy istnieje model „polskiego” euroregionu?, [in:] Malendowski, W., Szczepaniak, M. (ed.), Euroregiony: mosty do Europy bez granic, Wydawnictwo Elipsa, Warszawa.

Dziembała, M. (2013), Wspieranie innowacyjności gospodarek regionalnych $w$ świetle Strategii Europa 2020, 'Prace Naukowe Uniwersytetu Ekonomicznego w Katowicach', Katowice.

Fabish, I. (2011), Równość szans, [in:] Zdulski, Z., 20 lat współpracy transgranicznej $w$ Euroregionie Neisse-Nysa-Nisa, Wydawnictwo Ad Rem, Jelenia Góra.

Fujita, M., Mori, T. (2005), Frontiers of the New Economic Geography, 'Institute of Developing Economies. Discussion Paper', No. 27. 
Greta, M. (2003), Euroregiony a integracja europejska. Wnioski dla Polski, Wydawnictwo Uniwersytetu Łódzkiego, Łódź.

Greta, M. (2011), Institutional, Legal and Financial Aspects of the Functioning of Euroregions and Their Activity in the Youngest Polish Euroregions and Well as in the Oldest one: Bialowieza Forest, Szeszupa, Lyna-Lava and Neisse, Technical University of Lodz, Łódź.

Greta, M. (2013), Euroregiony polskie w procesie integracji oraz w przezwyciężaniu peryferyjnych dysproporcji regionalnych. Wydawnictwo Uniwersytetu Łódzkiego, Łódź.

Greta, M., Otto, J. (2013), Polish - German borderland in a "new dimension" of Euroregional activity: from Euroregional Pro Europa Viadrina, [in:] Piekutowska, A. (ed.), Economic and social aspects of cooperation among selected European countries, Politechnika Białostocka, Białystok.

Greta, M., Otto, J. (2013), The importance of Swiss Grants for creation of The Carpathian Euroregion marketing, 'Вісник', Kijów Wyd. Politechniki Lwowskiej, No. 762 Логістика.

Greta, M., Otto, J. (2018), Euroregion jako organizacja pozarządowa i potencjalny stymulator rozwoju turystyki transgranicznej, 'Ekonomiczne Problemy Turystyki' 1 (41).

Greta, M., Otto, J. (2018), Euroregionalna współpraca miast podzielonych na zachodnim pograniczu Polski - znaczenie dla rozwoju turystyki, 'Ekonomiczne Problemy Turystyki', 2 (42).

Greta, M., Tomczak-Woźniak, E. (2014), Euroregion i jego organizacyjny wpływ na możliwości efektywniejszego wykorzystania unijnej pomocy strukturalnej - na wybranym przykładzie. 'Przedsiębiorczość i Zarządzanie' Wyd. SAN, Tom XV, zeszyt 8 , część 1 .

Greta, M., Tomczak, E. (2013), Robert Schuman i Alcide de Gasperi - ludzie pogranicza w służbie idei zjednoczenia starego kontynentu, [in:] Tomczonek, Z. (ed.) Współpraca transgraniczna na obszarach pogranicza, Politechnika Białostocka, Białystok.

Grosse, T.G. (2007), Wybrane koncepcje teoretyczne i doświadczenia praktyczne dotyczace rozwoju regionów peryferyjnych, 'Studia Regionalne i Lokalne', No. 1 (27)

https://europa.eu/european-union/index_en (accessed: 2.07.2018).

http://www.coe.org.pl (accessed: 2.07.2018).

Huber, P. (2007), Regional labour market developments in transition, 'The European Journal of Comparative Economics”, No. 4 (2).

Jastrzębska, W. (2008), Rola euroregionów i współpracy transgranicznej w procesie integracji europejskiej, Wydawnictwo Uniwersytetu Łódzkiego, Łódź.

Kosmalski, R. (2011), Konwergencja i nierówności regionalne w Polsce w świetle metody DEA (rozprawa doktorska), Uniwersytet Ekonomiczny w Poznaniu, Wydział Informatyki i Gospodarki Elektronicznej, Poznań.

Krugman, P.R. (2007), Ekonomia międzynarodowa. Teoria i praktyka, t. 2, Wydawnictwo Naukowe PWN, Warszawa.

Kudełko, J. (2014), Uwarunkowania rozwoju regionalnego w świetle założeń euroregionalnej polityki spójności na lata 2014-2020, 'Studia Ekonomiczne', Uniwersytet Ekonomiczny w Katowicach, Katowice, No. 166. 
Kupiec, T. (2009), Rola regionów w Europie w kontekście polityki spójności UE, Wydział Rozwoju Regionalnego Urzędu Marszałkowskiego Województwa Śląskiego, Katowice.

Kusiak-Winter, R. (2011), Współpraca transgraniczna Polski i Niemiec-studium administracyjnoprawnego, 'Prace Naukowe Wydziału Prawa, Administracji i Ekonomii Uniwersytetu Wrocławskiego', No. 11.

Malarski, S. (2010), Euroregionu obszarów przygranicznych Polski oraz podstawy prawno-traktatowe stosunków Polski z państwami sąsiadującymi, [in:] Perkowski, M. (ed.) Współpraca transgraniczna. Aspekty prawno-ekonomiczne, Fundacja Prawo i Partnerstwo, Białystok.

Mazur-Wierzbicka, E. (2012), Koncepcja zrównoważonego rozwoju w praktyce społeczno-gospodarczej Unii europejskiej, 'Ekonomia', No. 4 (21).

Mempel-Śnieżyk, A. (2013), Koncepcje rozwoju regionalnego ze szczególnym uwzględnieniem klastrów i inteligentnych specjalizacji, 'Biblioteka Regionalisty', No. 13.

Nowak, P. (2011), Nowy paradygmat rozwoju regionalnego na przykładzie wybranych regionów Europy zachodniej (rozprawa doktorska), Uniwersytet Ekonomiczny w Poznaniu, Poznań.

Schmitt, N. (2002), L'émergence de régionalisme coopératif en Europe, Édicions Universitaires Fribourg, Fribourg.

Sodu, K. (2002), Foreign Direct Investment for Development. Maximizing Benefits Minimizing Costs, OECD Report.

Stappen, R. (2006), Brundtland Report, New York 2006.

\section{Streszczenie}

\section{Wielofunkcjonalność euroregionalna i jej znaczenie w aktywizacji obszarów przygranicznych}

Opracowanie dotyczy problematyki euroregionów w kontekście ich wielofunkcjonalności. Wielofunkcjonalność przedstawiono analizując strukturę instytucjonalną i realizowane cele. W ramach struktury instytucjonalnej przedstawiono funkcje poszczególnych instytucji euroregionu oraz znaczenie Stowarzyszenia Europejskich Regionów Granicznych (SERG) jako nadrzędnej reprezentacji euroregionów.

Odnosząc się do celów przedstawiono je w świetle założeń teoretycznych przyjętych dla tego typu struktur podkreślając iż w ich realizacji „kryje się" wielofunkcjonalność euroregionu. Ponadto zweryfikowano realizację celów w praktyce na przykładzie bezpośrednich badań empirycznych przeprowadzonych w wybranych polskich euroregionach tuż po ich powstaniu oraz z perspektywy kilkunastoletniego ich funkcjonowania. Pozytywne opinie w tym względzie, które przeważają w miarę wzrostu świadomości integracyjnej i dojrzewania euroregionu, przemawiają za celowością tworzenia takich struktur oraz za ich znaczeniem dla aktywizacji obszarów przygranicznych.

Słowa kluczowe: integracja europejska, region i polityka regionalna, euroregion 